\title{
Academic Leadership: A Tale of a Personal Experiment and Lessons Learned
}

\author{
Hugo A. Barrera-Saldaña* \\ Universidad Autónoma de Nuevo León, School of Medicine, Monterrey, Mexico
}

Scientists trained in institutions with well-developed cultures of academic excellence, such as those in the United States, Europe, Australia, and elsewhere, face a variety of difficulties when they return to their home countries to conduct research in institutions that do not yet have such mature cultures. While many scientists have found themselves in these situations, there are few accounts of how others have previously overcome such difficulties, including the best practices that they have used to meet the challenges encountered in such situations. I have dealt with some of these challenges myself. Such as when institutional leaders and even governmental agencies promoting academic excellence privileged quantity over quality in graduate training ${ }^{1}$ and when faculty failed to realize that the success of translational research relies on making it truly bidirectional ${ }^{2}$. I have also made my case to convince youth that a scientific career is indeed a life's privilege that offers the opportunity to contribute in important ways by serving humanity while enjoying a fantastic journey into the secrets of life ${ }^{3}$.

Most scientists who find themselves in these situations have been forewarned about the obstacles that await them, but there are few published accounts of how others in similar situations have been successful in raising academic standards. Articles recounting such successes would likely shorten the learning curves of those striving to improve academic standards when they return to their home nations. Hopefully, this brief description of personal experiences may thus prove useful to others, especially young scientists returning to positions in their home countries after training in institutions with well-established cultures of academic excellence.

My story centers around Dr. William "Jack" Schull, a world-renown American population geneticist from Houston, Texas, who passed away a few months ago at the age of 95 . He pioneered the study of the genetic effects of exposure to radiation from atomic bombs detonated in Hiroshima and Nagasaki, Japan, in 1945. He was a special mentor to me and many other leading geneticists he trained, both formally as his students and postdoctoral fellows, and more informally as his protégés, as was my case. I visited Jack frequently on my visits to Houston, most recently when I was invited to his $90^{\text {th }}$ and $95^{\text {th }}$ birthday celebrations. Every time I spoke with him, his life example and advice were both inspirational and educational.

The most significant impact Jack had on me, however, began some time ago when I was just embarking on a career as an independent researcher in a country (Mexico), a city (Monterrey), and an institution (Universidad Autónoma de Nuevo León) that were all striving to further develop cultures of academic excellence in their respective environments further. This happened in 1998 when the University of Texas Graduate School of Biomedical Sciences at Houston honored me with its Distinguished Alumni Award. During the ceremonial dinner, with my family, teachers, and friends in attendance, Jack proposed a toast in my honor saying, "Hugo is the

\section{Correspondence:}

Hugo A. Barrera-Saldaña

E-mail: habarrera@gmail.com
Date of acceptance: 20-02-2018

DOI: 10.24875/RMU.M18000012
Available online: 01-10-2018

Medicina Universitaria. 2018;20(2):103-106 www.medicinauniversitaria.org CC BY-NC-ND license (http://creativecommons.org/licenses/by-nc-nd/4.0/). 
only academician who, after having been identified as an outstanding candidate for a professorship in our Genetics Center, was dumb enough to turn me down!" He explained that "Hugo's naive excuse was that he wanted to return to Mexico to do something for his country." This remark 20 years ago has remained in my mind ever since. At times, it made me wonder what my career and life would have been like if I had joined Jack's well-established Genetics Center in Houston, but more often, it made me wonder if indeed I have been able to accomplish something significant for my country.

Fortunately, time has granted me the opportunity to live my own experiment in academic leadership, and I think it has given me some data to help me answer the question I have often posed to myself about contributions to "mi tierra (my homeland)." I am not referring to academic accomplishments and contributions to science - I will leave that assessment to my colleagues and peers in Mexico and other countries. Rather, my frame of reference is what I was able to accomplish in order to promote a culture of academic excellence, which at the time was considered a "luxury" by many people in positions at institutions where I have worked in Mexico.

While I was not consciously thinking about it at the time, the experiment began when I joined the Department of Biochemistry at the School of Medicine of the Autonomous University of Nuevo Leon in Monterrey, Mexico. I was tasked with developing Molecular Biology, which was the rising star of biomedicine at the time. It started with a real handicap - a laboratory that was practically in ruins. Soon I would come to see it as an advantage, as nobody envied my misfortune and thus my revolutionary crusade germinated inadvertently. Thus, "the experiment" began in an unusual environment:

- In a department in the area of basic research of a prestigious School of Medicine looking to relaunch their research and postgraduate programs;

- In the university leadership trying their best to honor the impressive history of the School and its affiliated University Hospital;

- With young scientists and students arriving from the region, the country, and the rest of Latin America, who were dreaming of entering the new discipline of molecular biology; and

- With the monumental effort of writing large, highly ambitious research proposals to funding agencies.

I suspect that those agencies were surprised to receive such proposals from a young researcher (rather than an established leader) promising to take the university from anonymity to stardom in the world of biomedicine. Funding such proposals was probably also a bit of an experiment for the agencies.

Having had the opportunity of training in the best laboratories of molecular biology in the world, in the USA and France, I viewed life in academia as an exciting, dignified, and honorable endeavor. At that early stage in my career, I was willing to meet any challenge and take on any sacrifice to be successful in academia. The only exception I could think of at the time was to ever leave my position as professor for that of an administrator, and "oh my God!" much less for that of a politician.

Moreover, that is the way it was for almost 10 years. I was happy building the "Unidad de Laboratorios de Ingeniería y Expresión Genéticas" (Unit of Laboratories of Genetic Engineering and Gene Expression), commonly referred to as ULIEG. Many brilliant researchers were trained there, important discoveries were made, and inventions conceived and developed. I believe that this record was unparalleled in Latin America and compared favorably to top-tier universities in the world, and owing to the accomplishments of ULIEG, the name of our University began to appear in the scientific biomedical communities throughout Mexico.

After a successful decade as a professor doing the research I loved, I was called in by the school leadership. They asked me for the third time, and said that it would be the last time they would ask, if I would accept the appointment as Head of the Department. Although I reluctantly accepted the decision, I must confess that it was one of the saddest days in my life as a professor. Would leaving my career as a productive researcher to become an administrative leader mean that my contributions to the biomedical world would decrease? This was a notion commonly held by faculty members in many of the academic circles abroad where I had trained and now frequented. Even worse, I feared that I might not yet have reached the level of success that I had dreamed of. Therefore, I was constantly looking for new things I could do for my beloved country-challenges like the ones my mentor, Jack Schull, had encouraged me to achieve. Thus, while my own laboratory continued to grow in reputation in Mexico and abroad, I felt that institutional politics would sooner or later jeopardize the future of this wonderful Unit as well as my own laboratory, and perhaps, I could make a significant contribution by preventing that from happening.

However, having endured for 10 years the dramatic transition from the first to the third world and having mastered the grant writing skills that were required; believing I had won the affection, respect, and even admiration of my colleagues; and knowing that the 
achievements at the ULIEG had led to its recognition as one of the most prestigious research centers in the country, I felt in a position to begin my era as Departmental Chairman "on the right footing." I was especially proud of how the ULIEG, with the trust and support of the faculty, transformed the department into probably the best in the University and one of the best in the country and illustrated to everyone how to bring excellence to academia and develop the culture to support it. There were many challenges and sacrifices, but also the reward of having trained many young students who soon were able to compete successfully for postdoctoral and/or academic positions at prestigious universities and research centers abroad, even becoming sought-after candidates. Within the country itself, many of our ex-alumni stand out as researchers, heads of major research centers, and leaders of departments at distinguished universities. Maybe I had done something for my country, and maybe becoming a Chairman would even allow me to do more?

Hence, as I undertook my new role, I was convinced that, in addition to creating the unique favorable circumstances mentioned above, the decisions we made and actions we took were usually correct, in large part because they were guided by a purpose higher than personal interests. Importantly, this driving force of our academic achievements was greater than the administrative goals of institutional leaders, and we stuck to them when the academic goals were not always viewed as paramount by administrators when decisions were made. Despite many questionings and criticisms, I was comfortable that we had always based our actions on the ideals and values of academia. Moreover, the academic excellence achieved at ULIEG surpassed that of peers who allowed themselves to be influenced by politics proved us right.

In summary, my personal experience entering academic leadership under challenging conditions in an environment without an existing culture of academic excellence has taught me that success in this type of leadership requires a great deal of preparation. The best, and perhaps, the only preparation for success in this environment is to devote oneself to being a serious scientist, pursue opportunities in the laboratories and institutions with cultures of true academic excellence, and realize that one must make the additional commitments to accept responsibility for the institution and/or department as well as one's own academic career. The goal should be to ultimately create cultures of excellence comparable to those that would enable success in a well-established institution in the highly developed nation.
I also share this experience as an act of responsibility and gratitude towards the academic community in Mexico (it all started with my BSc thesis directed by Francisco J Sánchez-Anzaldo) and my experience in the United States (where I continued to become a senior scientist under the guidance of Grady F. Saunders). I am also very grateful to the academic community in Europe (where I went to reaffirm my scientific skills in the laboratory of Pierre Chambon, one of the most competitive in the world) for the many opportunities and blessings it provided me. Anyone can learn good science and technology in the best laboratories in the world. However, where do you gain the wisdom necessary to confront the great challenges in order to cultivate the quality of science of world-leading established universities while being in a developing country whose institutions are now trying to raise their standards to that level?

Life has given me today the opportunity to share with those who also believe in the concept of academic excellence the practices they will have to employ if they want to succeed in their own crusades for scientific excellence.

\section{Best practices}

- Surround yourself with brilliant people, especially those more brilliant than you.

- Seize opportunities that present themselves and give your all to take advantage of them.

- Stay up to date on science - others will not follow you if you lack this credibility.

- Search for resources ceaselessly to transcend the mediocre and rise to excellence.

- Do not be afraid to use your authority, if you deserve it based on the merit of your performance and accomplishments.

- Lead through your continuing example of demanding excellence of yourself - but avoid boasting too much because that will awake the envy and the treason of the mediocre.

- Challenge students to achieve what they have not yet imagined.

- Be a vigorous advocate for the groups you lead within your institution and discipline.

- Identify and foster leadership in your colleagues, then give them leadership opportunities.

- Always hire talent and do not hesitate to let go of the mediocre - but try to do so in a professional and humane manner.

- Be prepared to be disputed by your pupils for pushing them too much - in the end, they will thank you 
for having prepared them with the discipline needed to triumph abroad.

For those who dare to follow these best practices of academic leadership, I extend my best wishes and hope that you may surpass what I and others may have accomplished; and for you, my dear Jack, my deepest gratitude for having been such a prominent inspiration in my crusade. I hope I did not disappoint you.

\section{Acknowledgments}

The author thanks George Stancel, Ph.D. and Ruby Delgado, MD for valuable comments and critical reading of the manuscript and Alfredo Delgado, Graciela López de Garza, Mario Gutiérrez and Alfredo Piñeyro who were leaders of the institution that trusted and supported this quixotic project.

The author wishes to dedicate this essay to the memory of Prof. Robert M. Chandler, who as Chairman of the Foreign Languages Department of our School and with his exceptional English editing skills strove to erase the handicaps associated with returning to practice science in the third world, helping our manuscripts (and our work) remain among the first world science elite.

\section{Funding}

The author acknowledges the many funds (SEP, CONACyT, PAICyT, UNESCO, donors, etc.), exceptional colleagues and students, and the rare well-intentioned university leadership that throughout three decades supported his quixotic effort to reach excellence in the graduate and research programs that flourished at UEIEG.

\section{References}

1. It's the academia, dummy! Or when quanity supersedes quality. Medicina Universitaria. 2016;18(70):58-9.

2. Barrera-Saldaña HA. Translational research in medicine: reverse the process and support it for success. Int J Cell Sci Mol Biol. 2017;2(1):555580.

3. Barrera-Saldaña HA. A journey from gene to gene families and into the whole genome. J Hum Genet Genomic Med. 1:103. 